\title{
Sebastian Bobowski
}

Uniwersytet Wrocławski

e-mail: sebastian.bobowski@gmail.com

ORCID: 0000-0002-1723-313X

\section{Jan Gola}

Uniwersytet Wrocławski

e-mail: golajan@op.pl

ORCID: 0000-0001-9236-9259

\section{POZACENOWE KRYTERIA OCENY OFERT \\ W SYSTEMIE ZAMÓWIEŃ PUBLICZNYCH. \\ W KIERUNKU NAJKORZYSTNIEJSZEJ \\ EKONOMICZNIE OFERTY*}

\section{NON-PRICE CRITERIA FOR THE EVALUATION \\ OF OFFERS IN THE PUBLIC PROCUREMENT SYSTEM. TOWARDS THE MOST ECONOMICALLY ADVANTAGEOUS OFFER}

DOI: $10.15611 / \mathrm{pn} .2018 .540 .03$

JEL Classification: H50, H57

\begin{abstract}
Streszczenie: Artykuł dotyczy doboru kryteriów oceny ofert w polskim systemie zamówień publicznych. Instytucja doboru odpowiednich czynników realizacji umowy zamówieniowej pełni istotną funkcję w wydatkowaniu środków publicznych. W opracowaniu wskazano m.in. na obowiązek zamawiającego dotyczący formułowania adekwatnych i proporcjonalnych wymagań w stosunku do wykonawców w celu realizacji jednej z podstawowych swoistych zasad prawa gospodarczego publicznego - zasady prawidłowego gospodarowania mieniem publicznym. Szczególny nacisk w artykule położono na pozacenowe kryteria oceny ofert, a także ich funkcję w społecznej gospodarce rynkowej. Dokonano także analizy ekonomicznej kryteriów oceny ofert oraz scharakteryzowano dwuetapowy proces oceny (ocena techniczna i finansowa), który jest często wykorzystywany przy ocenie ofert najkorzystniejszych ekonomicznie. Zwrócono także uwagę na stosowanie rankingu, uwzględniającego zagregowane oceny wynikające z przypisanych wag w relacji do oferowanej ceny.
\end{abstract}

Słowa kluczowe: kryteria oceny ofert, prawo zamówień publicznych, analiza ekonomiczna.

* Publikacja przygotowana w ramach projektu finansowanego ze środków Narodowego Centrum Nauki - decyzja DEC-2014/14/E/HS5/00845, umowa nr . 
Summary: The paper concerns the selection criteria for the evaluation of offers in the Polish public procurement system. The institution of selecting the appropriate factors for the implementation of the procurement contract plays an important role in the spending of public funds. The study indicated, among others, on the contracting authority's obligation to formulate adequate and proportional requirements from contractors in order to implement one of the basic specific principles of public economic law - the principle of proper management of public property. Particular emphasis in the paper was put on the non-price criteria for the evaluation of offers as well as their function in the social market economy. An economic analysis of the offer evaluation criteria was also carried out and a two-stage evaluation process (technical and financial assessment) was characterized, which is often used in the assessment of the most economically advantageous offers. Attention was also paid to the application of the ranking, taking into account the aggregate ratings resulting from the weightings assigned in relation to the offered price.

Keywords: criteria for the evaluation of offers, public procurement law, economic analysis.

\section{Wstęp}

System zamówień publicznych charakteryzuje się dużą innowacyjnością w sferze doboru kryteriów oceny ofert. Instytucja doboru odpowiednich czynników realizacji umowy zamówieniowej pełni istotną funkcję w wydatkowaniu środków publicznych. Zamawiający zobligowany jest do formułowania adekwatnych i proporcjonalnych wymagań od wykonawców w celu realizacji jednej z podstawowych swoistych zasad prawa gospodarczego publicznego - zasady prawidłowego gospodarowania mieniem publicznym. W opracowaniu zostaną przedstawione pozacenowe kryteria oceny ofert, a także ich funkcja w społecznej gospodarce rynkowej. Zostanie omówiona również płaszczyzna normatywna najkorzystniejszej ekonomicznie oferty, która oddziałuje również na właściwe zarządzanie w sektorze publicznym. Podstawową metodą badawczą zastosowaną w artykule jest metoda formalno-dogmatyczna, wykorzystano także analizę wskaźnikową.

\section{Kryteria oceny ofert w polskim systemie zamówień publicznych oraz najkorzystniejsza ekonomicznie oferta}

Normodawca w Ustawie z dnia 29 stycznia 2004 r. - Prawo zamówień publicznych ${ }^{1}$ wprowadził instytucję najkorzystniejszej oferty dla zamawiającego ${ }^{2}$. Jest to instytucja jurydyczna, która przedstawia najkorzystniejszy bilans ceny i innych kryteriów odnoszących się do przedmiotu zamówienia publicznego albo ofertę z najniższą $\operatorname{cen}^{3}$. Zamawiający najkorzystniejszą ofertę wybiera na podstawie kryteriów oceny

\footnotetext{
${ }^{1}$ Dz. U. z 2019 r., poz. 53 z późn. zm. Dalej: PZP.

2 Zob. art. 91 ust. 1 PZP.

3 Zob. art. 2 pkt 5 ustawy PZP.
} 
ofert określonych w specyfikacji istotnych warunków zamówienia4. Przedstawiciele doktryny publicznego prawa gospodarczego podkreślają rolę zamawiającego w zakresie konstrukcji oferty najkorzystniejszej dla konkretnego - zindywidualizowanego postępowania. To właśnie ten podmiot biorący udział w procesie wydatkowania środków publicznych ustala kryteria oceny ofert i nadaje im rangę. Ponadto w postępowaniu zamawiający ma najlepszą wiedzę, jakie kryteria zastosować i sam decyduje, która oferta będzie dla niego najkorzystniejsza"s.

Powyższe świadczy, że zamawiający może w każdym przypadku dobierać takie kryteria oceny ofert, które odnoszą się do przedmiotu zamówienia i odpowiadają realizacji jego obowiązku ustawowego ${ }^{6}$. Kryteriami oceny ofert są cena albo cena i inne kryteria odnoszące się do przedmiotu zamówienia, a przede wszystkim jakość, funkcjonalność, parametry techniczne, aspekty środowiskowe, społeczne, innowacyjne, serwis, termin wykonania zamówienia oraz koszty eksploatacji. W świetle powyższego należy stwierdzić, iż cena jest obligatoryjnym, lecz nie jednym kryterium oceny ofert, którym może posłużyć się zamawiający przy wyborze oferty najkorzystniejszej’ ${ }^{7}$ Ponadto warto zaznaczyć, że obok ceny zamawiający powinien co do zasady zastosować także inne kryteria odnoszące się do przedmiotu zamówienia ${ }^{8}$. Judykatura zaznacza na przykład, że „kryterium jakościowe wyraża najbardziej pożądane, istotne walory przedmiotu zamówienia, musi więc odnosić się do cech i właściwości, sposobu realizacji zamówienia, który jest dla zamawiającego ważny. W ocenie tego, co jest ważne, nie sposób przy tym zamawiającego zastępować, skoro to zamawiający decyduje, co zamierza nabyć, jakie cechy oferowany przedmiot ma posiadać, a także, które z możliwych cech tego przedmiotu są bardziej pożądane. Zawsze ocena tego, co jest lepsze lub gorsze, będzie dokonywana z pewnej perspektywy, z określonego punktu widzenia - przez pryzmat potrzeby zamawiającego. Kryterium jakościowe winno uwzględniać najlepsze rozwiązanie, zaś to, co jest najlepsze, winno być postrzegane przez przyjęte w danym zakresie kryterium oceny tego, co jest najbardziej pożądane z perspektywy celów postępowania i realizacji zamówienia".

Przedstawiciele doktryny zaznaczają, że kryteria wyboru oferty najkorzystniejszej mogą dotyczyć różnych jej aspektów, ale mają doprowadzić do wyboru ta-

${ }^{4}$ Zob. E. Wiktorowska, Organizacja, kwalifikacje i doświadczenie personelu wyznaczonego do realizacji zamówienia, Zamówienia Publiczne. Doradca, nr 5/2017, s. 70-73.

${ }^{5}$ M. Stachowiak, Komentarz do art. 2 ustawy - Prawo zamówień publicznych, lex.pl. Dostęp 24.12.2018.

${ }^{6}$ Zob. wyrok Krajowej Izby Odwoławczej z dnia 6 lipca 2017 r. (1210/17).

7 Zob. M. Kulińska, R. Siwik, Opracowanie koncepcji realizacji przedmiotu zamówienia jako kryterium oceny ofert, Zamawiający, nr 16/2016, s. 40-42.

${ }^{8}$ Zob. M. Lubiszewski, Właściwość wykonawcy jako kryterium oceny ofert $w$ postępowaniu o udzielenie zamówienia publicznego, Finanse Komunalne, nr 12/2017, s. 53-63; M. Gnela, Warunki serwisu dodatkowego jako kryterium oceny ofert przetargowych, Zamówienia Publiczne. Doradca, nr 10/2015, s. 53-59.

${ }^{9}$ Wyrok Krajowej Izby Odwoławczej z dnia 19 września 2016 r. (1580/16). 
kiej oferty, która jest najefektywniejsza ${ }^{10}$. Warto w tym miejscu przytoczyć pogląd K. Horubskiego, zgodnie z którym udzielanie zamówień może być uznane za formę administracji kierującej. Zdaniem autora „elementem kierowania administracyjnego w udzielaniu zamówień będzie niewątpliwie używanie przez zamawiających instrumentalnych kryteriów opisu przedmiotu zamówienia i oceny ofert. Kryteria instrumentalne, służąc realizacji celów społecznych lub ekologicznych, wymuszają na ubiegających się o zamówienie taki sposób jego wykonania, który przysłuży się realizacji pożądanych przez zamawiającego celów społecznych. Inaczej mówiąc, kryteria te nie mają waloru czysto ekonomicznego, tzn. nie służą uzyskaniu świadczenia o jak najwyższej jakości za jak najniższą cenę"11.

Wskazać należy, że wyliczenie innych niż cena kryteriów oceny ofert ma charakter tylko przykładowy i nie jest wyczerpujące. Zamawiający może stosować także inne kryteria oceny ofert niż wymienione w PZP. Samo „określenie tych kryteriów wraz z przypisaniem im określonej wagi należy do zamawiającego. To sam zamawiający decyduje o zastosowaniu określonych kryteriów oceny ofert kierując się specyfiką przedmiotu zamówienia oraz potrzebą uzyskania zamówienia na najkorzystniejszych warunkach"12.

Zaznaczyć należy, że kryteria pozacenowe stanowią rodzaj „,wsparcia dla opisu przedmiotu zamówienia i wyodrębniają obszary, w jakich dopuszczona jest konkurencja produktów czy rozwiązań, co przy prawidłowym opisie przedmiotu zamówienia i odpowiednio sformułowanych kryteriach powinno skutkować optymalnym wyborem w zakresie przedmiotu zamówienia"13. Ustawodawca zakazuje jednak stosowania przy ocenie ofert kryteriów o charakterze podmiotowym - właściwości wykonawcy ubiegającego się o zamówienie publiczne nie mogą być brane pod uwagę przy ocenie oferty najkorzystniejszej. Poza wiarygodnością ekonomiczną, techniczną lub finansową wykonawcy ubiegającego się o zamówienie przy wyborze najkorzystniejszej oferty nie mogą być brane pod uwagę także inne kryteria odnoszące się do właściwości wykonawcy. Ważny jest fakt, że „w ramach kryterium oceny ofert zamawiający zobowiązany jest badać już tylko cechy dotyczące przedmiotu zamówienia, czyli jego cenę, parametry, termin wykonania, itp. nie może oceniać cech wykonawcy, a więc np. jego doświadczenia. Zastosowanie kryteriów dotyczących właściwości wykonawcy jako kryteriów oceny ofert stanowi naruszenie

${ }^{10}$ Por. U. Sochacka, Aspekty społeczne w zamówieniach publicznych, Zamówienia Publiczne. Doradca, nr 11/2018, s. 69-78.

${ }^{11}$ K. Horubski, Publiczno- i prywatnoprawne elementy zamówień publicznych, Państwo i Prawo, nr $7 / 2009$, s. $72-84$.

12 https://www.uzp.gov.pl/baza-wiedzy/interpretacja-przepisow/opinie-archiwalne/kryteria-oceny-ofert-a-warunki-udzialu-w-postepowaniu-w-kontekscie-wymagania-przez-zamawiajacego-odwykonawcow-okreslonego-doswiadczenia, dostęp: 24.12.2018.

${ }^{13}$ I. Rzepkowska, Nieprawidłowości w stosowaniu kryteriów oceny ofert w postępowaniu o udzielenie zamówienia publicznego, Zamówienia Publiczne. Doradca, nr 11/2013, s. 70-78. 
art. 91 ust. 2 i 3 p.z.p.” ${ }^{14}$ Warto także wspomnieć, że „bez względu na kreatywność zamawiających w konstruowaniu pozacenowych kryteriów oceny ofert i sposobów jej urzeczywistniania nie można pomijać - przynajmniej w odniesieniu do podmiotów sektora finansów publicznych - zasady uzyskiwania najlepszych efektów z danych nakładów. Stąd też umiejętne operowanie elementami w ramach tego kryterium oceny ofert również jest niezwykle istotne"15. Niewątpliwie ta płaszczyzna normatywna wpływ na efektywność zamówień publicznych. To właśnie właściwy dobór kryteriów jest ,jednym z kluczowych działań zamawiającego, które mają zasadniczy wpływ na efektywność zamówienia publicznego. Oceniając dobór omawianych kryteriów z ekonomicznego punktu widzenia musimy stwierdzić, że mają one pozwolić zamawiającemu na dokonanie racjonalnego wyboru w sytuacji, w której zazwyczaj jego zasoby są ograniczone"16.

Istotną rolę odgrywają kryteria dotyczące innowacyjności. Są one coraz częściej stosowane i brane pod uwagę w postępowaniu o udzielenie zamówienia publicznego. Trzeba jednak pamiętać, że stosowanie kryteriów dotyczących innowacyjności wiąże się z większymi komplikacjami związanymi z przygotowaniem zamówienia. Ponadto ,zamawiający musi zbadać nie tylko rynek istniejących i działających rozwiązań w danej dziedzinie, musi umieć zbadać i ocenić interesujące go nowe produkty. Dodatkowo zakup lub wdrożenie produktów innowacyjnych zawsze wiąże się ze zwiększonym ryzykiem (...). Zamawiający, oprócz konieczności stworzenia mechanizmu umożliwiającego ocenę lub stopniowanie innowacyjności produktu, musi być gotowy na poniesienie zwiększonego ryzyka wiążącego się z zakupem produktu nowego i choć dopuszczonego do obrotu, z pewnością wymagającego dalszego testowania i udoskonalania" ${ }^{17}$.

Co istotne, regulacje PZP uznają za niedopuszczalne stosowanie przy wyborze najkorzystniejszej oferty takich kryteriów oceny ofert, jak doświadczenie wykonawcy czy też posiadanie przez wykonawcę znajomości określonej branży. Jednak należy podkreślić, że niedopuszczalne aspekty, tj. doświadczenie wykonawcy czy też posiadanie przez niego znajomości określonej branży, zdobytej w trakcie wykonywania podobnych zamówień dla podmiotów działających $\mathrm{w}$ określonej branży, mogą stanowić warunki udziału w postępowaniu. Posiadanie przez wykonawcę doświadczenia $\mathrm{w}$ realizowaniu określonych zamówień nie pozostaje bez znaczenia dla oceny możliwości udzielenia zamówienia publicznego temu wykonawcy. Wskazuje się, że „zamawiający ma możliwość określenia warunków udziału w postępowaniu

14 R. Niemczyk, Podmiotowe kryteria wyboru oferty, Monitor Zamówień Publicznych, nr 11/2015, s. $39-40$.

${ }_{15}$ M. Brzeziński, D. Ćwik, Sposób wykonania zamówienia jako kryterium oceny ofert, Zamawiający, nr 29/2018, s. 58-62.

${ }^{16}$ P. Nowicki, Efektywne zamówienia publiczne jako rezultat stosowania nowego podejścia do zamówień publicznych, Warszawa 2013, s. 45.

${ }^{17}$ F. Łapecki, Pozacenowe kryteria oceny ofert jako mierniki wartości transakcyjnej, Zamówienia Publiczne. Doradca, nr 5/2017, s. 59-69. 
tak, aby zapewnić udzielenie zamówienia publicznego wykonawcy gwarantującemu należyte wykonanie zamówienia"18.

\section{Analiza ekonomiczna pozacenowych kryteriów oceny ofert ${ }^{19}$}

W toku postępowania o udzielenie zamówienia wybiera się ofertę najkorzystniejszą ekonomicznie - w przypadku uwzględnienia zestawu dodatkowych kryteriów poza ceną, lub ofertę o najniższej cenie. Druga metoda stosowana jest najczęściej, choć najtańsza oferta nie zawsze przekłada się na najlepszy efekt zrealizowanego zamówienia. W przypadku wyboru oferty najkorzystniejszej ekonomicznie pojawiają się dodatkowe mierzalne i niemierzalne kryteria, przy czym te ostatnie należy odpowiednio skwantyfikować. Kryteria oceny obejmować mogą m. in. cenę, jakość, wartość techniczną, opłacalność, koszty użytkowania, właściwości estetyczne i funkcjonalne, aspekty środowiskowe, wsparcie techniczne, datę dostawy i czas realizacji, pewność i ciągłość dostaw, usługi posprzedażowe, koszty cyklu życia.

Dwuetapowy proces oceny (ocena techniczna i finansowa) jest często wykorzystywany przy ocenie ofert najkorzystniejszych ekonomicznie. Na etapie oceny technicznej punkty są przydzielane na podstawie indywidualnych kryteriów (innych niż cena), a każdemu kryterium przypisuje się określoną wagę w dokumentacji. $\mathrm{Na}$ etapie oceny finansowej porównuje się względne koszty poszczególnych ofert. Następnie przygotowywany jest ranking, uwzględniający zagregowane oceny wynikające z przypisanych wag $\mathrm{w}$ relacji do oferowanej ceny.

Tabela 1 przedstawia przykładowe kryteria oceny technicznej. Współczynniki wagi są wyrażone jako wartości procentowe sumujące się do 100. Do każdego kryterium przypisano ocenę nominalną z przedziału 80-120, gdzie 100 oznacza, że wszystkie wymagania określone w dokumentacji przetargowej zostały spełnione, 120 świadczy o przekroczeniu niektórych lub wszystkich wymagań zapisanych w dokumentacji przetargowej, natomiast 80 oznacza, że nie wszystkie wymagania zostały spełnione, jednakże oferta została przyjęta ze względu na niewielki zakres odnotowanych odstępstw.

$\mathrm{Na}$ etapie oceny finansowej dokonywany jest przegląd ofert pod kątem cen, a koszt względny C każdej oferty szacuje się jako wartość procentową oferty najtańszej.

18 https:/www.uzp.gov.pl/baza-wiedzy/interpretacja-przepisow/opinie-archiwalne/kryteria-oceny-ofert-a-warunki-udzialu-w-postepowaniu-w-kontekscie-wymagania-przez-zamawiajacego-odwykonawcow-okreslonego-doswiadczenia, dostęp: 24.12.2018.

${ }^{19}$ Szerzej o ewaluacji ofert najkorzystniejszych ekonomicznie: S. Bobowski, J. Gola, W. Szydło, M. Przybylska, The Most Economically Advantageous Tender in the Public Procurement System in the European Union, [w:] Eurasian Studies in Business and Economics, Springer, Cham, w druku. 
Tabela 1. Ocena techniczna kontraktu

\begin{tabular}{|l|c|c|c|}
\hline \multicolumn{1}{|c|}{ Kryterium oceny } & $\begin{array}{c}\text { Współczynnik wagi (1) } \\
(\%)\end{array}$ & Ocena nominalna (2) & $\begin{array}{c}\text { Ocena ważona } \\
(3)=(1) \times(2)\end{array}$ \\
\hline Kryterium 1 & 15 & 80 & 12 \\
\hline Kryterium 2 & 20 & 90 & 18 \\
\hline Kryterium 3 & 30 & 100 & 30 \\
\hline Kryterium 4 & 35 & 120 & 42 \\
\hline Rezultat oceny technicznej & & 102 \\
\hline
\end{tabular}

Źródło: opracowanie własne na podstawie: Public Procurement Best Practice Guide, Public Procurement Directorate, 2013; online: http://www.publicprocurementguides.treasury.gov.cy/OHSEN/ HTML/index.html? 2_7_6_what_criteria_should_i_use_to_award_htm. Dostęp: 19.12.2018.

Przykładowo jeśli najniższa cena oferowana w przetargu wynosi 40000 euro, a oferent zaoferował 70000 euro, cenę oferty oblicza się w następujący sposób:

$$
K=\{(40000) /(70000)\} \times 100=57,14 .
$$

Oferta z najniższą ceną otrzymuje 100 punktów. Ważenie wartości technicznej zamówienia w relacji do sugerowanej ceny następuje przez wybór odpowiedniego współczynnika wagi, tak jak w przypadku wspomnianego wyżej dwuetapowego procesu oceny. Konieczny jest wybór odpowiedniego współczynnika $n$, który określi ostateczny ranking ofert uporządkowanych według malejącej wartości zagregowanej oceny $L$, obliczonej przy użyciu następującego wzoru:

$$
L=T \times n+C \times(1-n),
$$

gdzie: $T$ - rezultat oceny technicznej, $C$ - względny koszt finansowy oferty, $n$ - współczynnik wagi służący ważeniu wartości technicznej zamówienia w relacji do proponowanej ceny.

Przyjmując czynnik wagi na poziomie $70 \%$, należy stwierdzić, że ostateczna ocena wyniesie:

$$
L=(102 \times 0,70)+(57,14 \times 0,30)=88,54 .
$$

W związku z tym w przypadku wyboru oferty najkorzystniejszej ekonomicznie należy najpierw wybrać kryteria, a następnie przypisać odpowiednie wagi wartości technicznej zamówienia w relacji do proponowanej ceny.

Wysoka wartość współczynnika wagi $n$, tj. ponad $70 \%$, powoduje, że wybrana zostaje oferta o najwyższej technicznej wartości zamówienia, natomiast niska wartość współczynnika wagi $n$, tj. poniżej $60 \%$, oznacza, że kryterium oferty najkorzystniejszej ekonomicznie zostaje odrzucone na rzecz kryterium najniższej ceny. Innymi słowy współczynnik wagowy $n$ określa koszty finansowe, które poniesie zamawiający, aby wybrać ofertę o wyższej wartości technicznej. Dlatego też zdefiniowanie odpowiedniego współczynnika wagi ma kluczowe znaczenie, daje bowiem możliwość uzyskania najlepszej relacji jakości do ceny. 
Jeśli się przyjmie wartość współczynnika wagi na poziomie $70 \%$, waga wartości technicznej zamówienia w stosunku do zamówienia $(n=70 \%)$, proporcja $n /(100$ $-n)=70 / 30=2,33$ oznacza, że zamawiający akceptuje cenę wyższą o $2,33 \%$, aby uzyskać wzrost wartości technicznej zamówienia o $1 \%$, cenę wyższą o $4,66 \%$, aby uzyskać wzrost wartości technicznej zamówienia o 2\%, cenę wyższą o 6,99\%, aby uzyskać wzrost wartości technicznej zamówienia o 3\%, cenę wyższą o 9,32\%, aby uzyskać wzrost wartości technicznej zamówienia o 4\% itp. W takim przypadku, gdy oferta finansowa okaże się wyższa o 2,5\% w porównaniu z innymi ofertami konkurencyjnymi, podczas gdy wartość techniczna zamówienia jest niższa o $1 \%$, preferowany będzie oferent o niższej cenie i niższej wartości technicznej. $Z$ drugiej strony, gdy oferta finansowa jest wyższa o 2,2\% od oferty konkurencyjnej, podczas gdy wartość techniczna zamówienia jest niższa o $1 \%$, preferowany będzie oferent o wyższej cenie i wyższej wartości technicznej zamówienia.

Jeśli z kolei przyjęty zostanie wskaźnik wagi w wysokości $60 \%$, waga wartości technicznej umowy w stosunku do ceny $(n=60 \%)$, proporcja $n /(100-n)=60 / 40$ = 1,5 oznacza, że zamawiający akceptuje cenę wyższa o 1,5\%, aby uzyskać wzrost wartości technicznej zamówienia o $1 \%$, cenę wyższą o $3 \%$, aby uzyskać wzrost wartości technicznej zamówienia o $2 \%$, cenę wyższą o 4,5\% w celu uzyskania wzrostu wartości technicznej zamówienia o $3 \%$, cenę wyższą o $6 \%$, aby uzyskać wzrost wartości technicznej zamówienia o $4 \%$ itd. W związku z tym w przypadku gdy oferta finansowa jest wyższa o 1,6\% w porównaniu z innymi ofertami konkurencyjnymi, podczas gdy wartość techniczna zamówienia jest niższa o $1 \%$, preferowany będzie oferent oferujący niższą cenę i niższą wartość techniczną zamówienia. $Z$ drugiej strony, gdy oferta finansowa jest wyższa o $1,4 \% \mathrm{w}$ porównaniu z innymi ofertami konkurencyjnymi, podczas gdy wartość techniczna zamówienia jest niższa o 1\%, wybrany zostanie oferent z wyższą ceną i wyższą wartością techniczną zamówienia. $\mathrm{W}$ tym przypadku proporcja jest wyraźnie mniejsza niż w przypadku poprzedniego przykładu.

\section{Podsumowanie}

Konkludując powyższą materię badawczą, należy zaznaczyć, że w celu zapobiegania nieprawidłowościom w procesie udzielania zamówienia publicznego należy dążyć do ograniczenia możliwości subiektywnej oceny kryteriów przez zamawiającego. Powinno się dążyć do „szczegółowości, kompletności i jednoznaczności opisu kryteriów oceny ofert umożliwiającej każdemu znającemu treść ofert dokonanie ich właściwej i obiektywnie uzasadnionej oceny oraz hierarchizacji w rankingu ofert" ${ }^{20}$. Natomiast zastosowanie kryteriów niewymiernych w sposób naturalny rodzi obawy o zachowanie rzeczowej i obiektywnej oceny złożonych ofert. Ponadto „dla zapewnienia uczciwej konkurencji w tym zakresie zasadnicze znaczenie ma takie opisanie

${ }^{20}$ R. Baczewski, Naruszenia dotyczące kryteriów oceny ofert, Zamawiający, nr 13/2015, s. 24-29. 
kryteriów niewymiernych, aby wykonawcy byli w pełni świadomi, jakie aspekty realizacji zamówienia będą brane przez zamawiającego pod uwagę przy ich ewaluacji. Trudno zatem wyobrazić sobie opisanie tych kryteriów bez udziału osób merytorycznych, potrafiących m.in. ocenić, czy i jakie znaczenie dla zamawiającego może mieć dany aspekt realizacji zamówienia"21.

Istotne jest także, że zamawiający ma obowiązek przypisać określoną wagę każdemu z kryteriów, a „ustala się to w ten sposób, że każdemu z kryteriów zamawiający przypisuje liczbę procentową, przy założeniu, iż wszystkie kryteria łącznie stanowią 100\%. Tym samym sposób oceny ofert powinien być tak realizowany, aby ograniczyć subiektywne odczucia i osobiste preferencje, a zapewniać ocenę ofert w zgodzie z zasadą uczciwej konkurencji i równego traktowania wykonawców"22. Nie należy także zapominać, że powyższe obostrzenia wpływają na przestrzeganie zasady równego traktowania wykonawców, która należy do jednych z podstawowych zasad udzielania zamówień publicznych.

\section{Literatura}

Adamczyk W., Udział pracowników merytorycznych w przygotowaniu i przeprowadzeniu postępowania, Zamawiający, nr 5/2014.

Baczewski R., Naruszenia dotyczące kryteriów oceny ofert, Zamawiający, nr 13/2015.

Bobowski S., Gola J., Szydło W., Przybylska M., The Most Economically Advantageous Tender in the Public Procurement System in the European Union, [w:] Eurasian Studies in Business and Economics, Springer, Cham, w druku.

Brzeziński M., Ćwik D., Sposób wykonania zamówienia jako kryterium oceny ofert, Zamawiający, nr 29/2018.

Dz. U. z 2019 r., poz. 53 z późn. zm.

Gnela M., Warunki serwisu dodatkowego jako kryterium oceny ofert przetargowych, Zamówienia Publiczne. Doradca, nr 10/2015.

Horubski K., Publiczno- i prywatnoprawne elementy zamówień publicznych, Państwo i Prawo, $\mathrm{nr} 7 / 2009$.

https://www.uzp.gov.pl/baza-wiedzy/interpretacja-przepisow/opinie-archiwalne/kryteria-ocenyofert-a-warunki-udzialu-w-postepowaniu-w-kontekscie-wymagania-przez-zamawiajacego-odwykonawcow-okreslonego-doswiadczenia.

Kulińska M., Siwik R., Opracowanie koncepcji realizacji przedmiotu zamówienia jako kryterium oceny ofert, Zamawiający, nr 16/2016.

Lubiszewski M., Właściwość wykonawcy jako kryterium oceny ofert w postępowaniu o udzielenie zamówienia publicznego, Finanse Komunalne, nr 12/2017.

Łapecki F., Pozacenowe kryteria oceny ofert jako mierniki wartości transakcyjnej, Zamówienia Publiczne. Doradca, nr 5/2017.

Niemczyk R., Podmiotowe kryteria wyboru oferty, Monitor Zamówień Publicznych, nr 11/2015.

Nowicki P., Efektywne zamówienia publiczne jako rezultat stosowania nowego podejścia do zamówień publicznych, Warszawa 2013.

${ }^{21}$ W. Adamczyk, Udziat pracowników merytorycznych w przygotowaniu i przeprowadzeniu postępowania, Zamawiający, nr 5/2014, s. 12-17.

${ }^{22}$ Wyrok Krajowej Izby Odwoławczej z dnia 2 marca 2016 r. (163/16). 
Public Procurement Best Practice Guide, Public Procurement Directorate, 2013; online: http://www. publicprocurementguides.treasury.gov.cy/OHSEN/HTML/index.html?2_7_6_what_criteria should_i_use_to_award_htm.

Rzepkowska I., Nieprawidlowości w stosowaniu kryteriów oceny ofert w postępowaniu o udzielenie zamówienia publicznego, Zamówienia Publiczne. Doradca, nr 11/2013.

Sochacka U., Aspekty społeczne w zamówieniach publicznych, Zamówienia Publiczne. Doradca, nr 11/2018.

Stachowiak M., Komentarz do art. 2 ustawy - Prawo zamówień publicznych, lex.pl.

Wiktorowska E., Organizacja, kwalifikacje i doświadczenie personelu wyznaczonego do realizacji zamówienia, Zamówienia Publiczne. Doradca, nr 5/2017.

Wyrok Krajowej Izby Odwoławczej z dnia 19 września 2016 r. (1580/16).

Wyrok Krajowej Izby Odwoławczej z dnia 2 marca 2016 r. (163/16).

Wyrok Krajowej Izby Odwoławczej z dnia 6 lipca 2017 r. (1210/17). 